\title{
Mónica Ghirardi (Coordinadora). Territorios de lo cotidiano. Siglos XVI-XX. Del antiguo virreinato del Perú a la Argentina contemporá- nea. Rosario: Prohistoria Ediciones, 2014, 306 páginas.
}

\author{
Luna Sofía Dobal ${ }^{1}$
}

E ste nuevo aporte historiográfico coordinado por Mónica Ghirardi reúne un

— conjunto de valiosos trabajos de reconocidos investigadores, quienes abordan como temática de interés las múltiples aristas del territorio de la vida cotidiana desde una perspectiva de larga duración que recorre la vida colonial hasta la Argentina contemporánea. Así, diferentes territorios y temporalidades se cruzan en este libro para aportar una compleja variedad de miradas y análisis desde perspectivas metodológicas y teóricas diversas que enriquecen el campo de estudio de esta problemática y de nuestra disciplina en general. Con una lograda articulación, las seis secciones que conforman la totalidad del texto consiguen que las temáticas de cada artículo "dialoguen" entre sí, permitiendo que los lectores, al tiempo que se acercan a aspectos novedosos de esa minuciosa reconstrucción histórica, puedan reflexionar de modo ameno y creativo al punto de "viajar en la lectura" de cada aspecto que surcó lo cotidiano.

La primera sección titulada: Familia de elite, mujeres, sangre y patrimonios reúne dos trabajos, el de Ana María Presta y el de Marcelo Gershani Oviedo, quienes nos aproximan a la vida cotidiana de dos protagonistas mujeres que tuvieron su experiencia de vida en distintos tiempos y espacios. Juana (que vivió en Charcas en el siglo XVI) y María Alejandra (que vivió en Catamarca en la segunda mitad del siglo XIX) quedaron ambas situadas en el seno de conflictos intrafamiliares por la disputa de las herencias. Lugares distintos y temporalidades diferentes muestran cómo las relaciones familiares se hallaban inmersas en un entramado social y cultural que forjaba roles y que establecía regulaciones de las cuales varones y mujeres no se podían desprender. El peso de la tradición del mandato patriarcal y de las relaciones de género con sus consecuentes dependencias no daba lugar a la libre decisión.

En la segunda sección: Guerra, poderes, instituciones y política, el entramado social estudiado por cada autor ilustra una red de relaciones que se

1 Universidad Nacional del Centro de la Provincia de Buenos Aires. Argentina. Correo electrónico:

lunadobal@gmail.com 
entreteje al compás de diversas acciones que componen la vida cotidiana. Por un lado, Federico Sartori expresa cómo las "insignias de poder" fueron utilizadas por los comisarios de la Córdoba del 1600, bajo la matriz de las costumbres y organización del sistema de la inquisición e impregnaron de simbolismo el accionar cotidiano. Por su parte, el artículo de Elsa Caula muestra cómo se armó una red de familias en la que se yuxtaponía lo político, lo diplomático y la lealtad al Rey Fernando VII, condicionando las labores diarias y los roles sociales en la época de las revoluciones.

Las fuentes analizadas en la tercera sección: Esclavos, indios y enfermos de los sectores populares en la cotidianidad colonial, como en general a lo largo del libro, nos acercan a personajes de la historia que antes habían sido olvidados o aguardaban en la oscuridad de los archivos para ser descubiertos. María Laura Salinas estudia la vida cotidiana en un pueblo de indios durante el siglo XVII en Alto Paraná y Paraguay, su análisis permite vislumbrar las transformaciones y las permanencias de prácticas y hábitos en la fusión cultural. Kris Lane analiza el impacto que tuvo la Casa de la Moneda en la vida cotidiana de los esclavos de las minas de plata durante el siglo XVII. En ambos artículos se puede observar un intercambio entre viejas y nuevas costumbres, dando luz a una vida cotidiana transformada y apropiada por los propios sujetos en diálogo con su contexto histórico. En tanto, Jovita María Novillo estudia la vida de un esclavo a fines del siglo XVIII, las fugas en busca de su anhelada libertad y las estrategias que fue adoptando para poder alcanzarla. Por último, Mónica Ghirardi y Liliana Pizzo nos introducen en una investigación muy detallada referida a las complicaciones de la vida cotidiana en Córdoba (1762-1775), a través del análisis de los registros que dejaron los frailes betlemitas sobre las enfermedades, las atenciones y labores que realizaban en esos años; asimismo, las autoras nos muestran las diferencias en las atenciones recibidas en cuestiones como la edad, el género y el grupo social de pertenencia, entre otras.

En la cuarta sección: Sociedad, población, estrategias familiares y prácticas de movilidad. Siglo XVIII y primera mitad del Siglo XIX y Segunda mitad del Siglo XIX y Siglo XX (en dos apartados), nos encontramos con los trabajos de Dora Celton, Claudio Küffer y Sonia Colantonio, quienes en conjunto indagan las formas de control político que se dieron durante la creación del virreinato del Río de la Plata. A partir del análisis se identifican algunas transformaciones en la sociedad de Tulumba donde los negros ensayaron una serie de acciones y estrategias a través del mestizaje, el blanqueamiento y la movilidad social, apelando como recurso a las uniones matrimoniales. Tal como se plantea en el trabajo, esa movilidad generada por el mestizaje social puede ser comprendida y percibida como un "desorden social" y una transgresión respecto del control 
político propio de la organización del virreinato. En cuanto al texto de Gloria López Nones, la autora realiza un estudio sobre la sociedad mendocina tardocolonial y Patricia Sánchez analiza los espacios de sociabilidad tanto públicos como privados en San Juan de la Frontera durante la primera mitad siglo XIX; ambos artículos tratan de vislumbrar las diferentes prácticas sociales que se llevaron a cabo en el cotidiano tantos en espacios públicos y privados.

En el segundo apartado, Bibiana Andreucci muestra cómo se realizó la fundación de la ciudad de Chivilcoy (1854) y las permanencias y transformaciones que se dieron en lo que fue la expansión de la frontera bonaerense en la primera mitad del siglo XIX. En cuanto Juan Pablo Ferreiro, indaga cómo los apellidos son una ilustración de las redes sociales y de vínculos parentales y de compadrazgo que se fueron dando en el oriente jujeño relacionados con la producción ganadera y agricultora de la zona. El trabajo de José Luis Moreno plantea la convivencia de dos mundos, de dos culturas a partir del análisis del caso de una familia de inmigrantes italianos y el envío de remesas al país de origen. Con eficacia el autor consigue articular el enfoque macroeconómico con una visión "micro histórica".

En la quinta sección: Lo cultural y lo simbólico en las prácticas y espacios de lo cotidiano se examinan las transformaciones del espacio y las adaptaciones al mismo en las prácticas y acciones diarias. Ya sea en los espacios públicos o privados, cada uno va estableciendo lógicas de comportamiento o ellas son las que en otras situaciones van apropiándose de los espacios, Ilenándolos de sentidos. La investigación que Cecilia Moreyra desarrolla en su artículo da cuenta de las transformaciones que se dan en los espacios y en el mobiliario y el modo en que eso impacta y modifica o no los hábitos y costumbres de la vida cotidiana. Por su parte, el aporte Paula Bontempo analiza cómo la lectura fue un hábito que se fue incorporando y cooptando espacios y tiempo en la vida de las personas; muestra con solidez que el placer por la lectura más que ser una experiencia planificada y estructurada fue un tipo de práctica de los ratos libres que se realizaba al viajar o trasladarse.

En la sexta y última sección: Militancias, políticas y sexualidad confluyen ideas distintas sobre la década de los sesenta. Diferentes miradas y prácticas dieron formas a ámbitos cotidianos divergentes en un mismo contexto histórico. Desde la pasión, los lazos afectivos y la experiencia sexual en la militancia guerrillera de izquierda, presentada en el artículo de Isabella Cosse, a los discursos del movimiento familiar cristiano cordobés que perseguía los ideales de familia heterosexual y monógama, cuidadosa y base de la enseñanza de una sexualidad adaptada a la moral cristiana presentados por Sara Moyano.

Como reflexión final, este libro abre un abanico de experiencias y nutre 
profundamente a quien se sumerge en la lectura de la vida cotidiana. Los territorios aquí se hallan señalados no sólo por un espacio geográfico concreto, sino que se vuelven una construcción cuasi dialéctica con las prácticas diarias. Finalmente, cabe destacar que la incorporación de gráficos, estadísticas, citas de las fuentes e imágenes que hicieron los autores posibilitan una mejor comprensión y una invitación a reflexionar sobre la riqueza y la potencialidad de esas investigaciones que nos aproximan a los "territorios de la vida cotidiana". 